\title{
Level of occupational stress of court probation officers and style of coping with stress
}

\author{
Łukasz Wirkus \\ Department of Social Sciences, Pomeranian University in Słupsk, Poland
}

\begin{abstract}
BACKGROUND
The relationship between a court probation officer and their ward is a specific one and is frequently connected with enormous individuals costs. This fact is connected with the character of the job, and with the conditions determining its character. Psychosocial threats may influence both mental and somatic health, directly or indirectly, by means of the influence exerted by stress.
\end{abstract}

\section{PARTICIPANTS AND PROCEDURE}

The main study was conducted at the offices of the teams of the Court Probation Service. The teams of the Court Probation Service are part of the structure of the following 9, randomly selected, district courts (DCs): DC Wrocław, DC Bydgoszcz, DC Szczecin, DC Poznań, DC Łódź, DC Lublin, DC Kraków, DC Katowice and DC Białystok. Participation in the research was voluntary and anonymous; the tools were arranged in sets, and the sequence of those sets was random. The sets of research tools were received by 1,000 individuals altogether.

\section{RESULTS}

The conducted research confirmed the need to verify the significance of the feeling of occupational stress of court probation officers at the workplace and the correlations between it and a number of variables. I present statistical analyses concerning various aspects of occupational stress experienced in the studied group, including correlations between the general level of occupational stress and the dimensions of it, and organizational predictors. The objective of the research was to indicate the styles of coping with stress and the correlations of them with the stress felt by court probation officers.

\section{CONCLUSIONS}

The research confirms a significant influence exerted by organizational determinants upon the general level of felt occupational stress. Professional court probation officers experience a higher level of felt occupational stress; what is conducive to that is high encumbrance with occupational responsibilities, and also functioning directly in structures of the court of law. Court probation officers suffering from high and low levels of occupational stress differ from one another in terms of the selection of the style concentrated on emotions, which is relevant to the style typical of individuals manifesting the propensity for concentrating on themselves and their own emotional experiences. The individuals manifesting a high level of felt occupational stress select the style described in this paper much more frequently than individuals suffering from a low level of stress.

\section{KEY WORDS}

probation officer; job stress; style of coping; Court Probation Service

Corresponding Author - Łukasz Wirkus, Ph.D., Department of Social Sciences, Pomeranian University in Słupsk, 64 Bohaterów Westerplatte Str., 76-200 Słupsk, Poland, e-mail: wirkus.l@gmail.com

AUthors' CONTRIBUtion - A: Study design - B: Data collection - C: Statistical analysis - D: Data interpretation .

E: Manuscript preparation · F: Literature search · G: Funds collection

TO CITE THIS ARTICLE - Wirkus, Ł. (2015). Level of occupational stress of court probation officers and style of coping with

stress. Current Issues in Personality Psychology, 3(4), 214-229.

RECEIVED 21.07.2015 · REVIEWED 31.07.2015 · ACCEPTED 06.08.2015 · PUBLISHED 19.08.2015 


\section{BACKGROUND}

The Act on Court Probation Officers of $27^{\text {th }}$ July, 2001, constitutes the legal foundation of the existence and activities of the Court Probation Service and determines the general principles of the functioning of court probation officers. In accordance with Article 1 of that Act, court probation officers perform the tasks with which they have been entrusted by virtue of legal provisions within the scope of education and resocialization, diagnostics, prophylaxis and monitoring, connected with carrying out the decisions of the court of law. Court probation officers perform the tasks with which they have been entrusted in the milieu of their wards, and also in high-security facilities and institutions. Court probation officers are further classified into professional and voluntary court probation officers, who carry out decisions in criminal cases or in cases involving family, and also in relation with juveniles (The Act on Court probation officers, 2001). The tasks of the Court Probation Service are diverse, and they are performed in a number of different contexts. In the year 2013, professional court probation officers were performing their tasks in the 401,403 cases of individuals convicted by virtue of the sentences of criminal courts, and also in 173,199 cases of the wards of the family courts of law. Court probation officers conducted 676,522 community interviews, and the average number of cases with which a court probation officer in charge of adult individuals was entrusted was 128.60 , whereas in the case of a court probation officer in charge of the family that number was 72.40 cases. Professional court probation officers in charge of adult individuals are performing an ever-increasing number of tasks resulting from the broader scope of the application of the means of electronic supervision. Court probation officers in charge of the family are being encumbered to an increasing degree with difficult (and attracting the attention of the mass media) cases relevant to participation in taking a child away from their parents(s), and also in the contacts between an authorized individual and a child. Court probation officers participate in a wide scope in national politics in the sphere of counteracting violence within the family. In the year 2013, 3,048 court probation officers served in the capacity of members of interdisciplinary teams; court probation officers participated in 20,500 meetings of 13,000 working groups, which were established in order to ascertain the occurrence of violence in the family (The National Council of Court probation officers, 2014).

The relationship between a court probation officer and their ward is a specific one, and is frequently connected with enormous individuals costs. This fact is connected with the character of the job, and with the conditions determining its character. What is of significance in this context is the personality construct of a court probation officer, which determines the effectiveness of tasks undertaken within the scope of education and resocialization, diagnostics, prophylaxis and monitoring. In that relationship, an enormous role is played by close interpersonal contact, taking advantage, as well, of the processes of commitment and emotional exchange (Sęk, 2000). Organization psychologists and sociologists confirm the significant correlation between occupational stress and the negative attitudes and behaviours of employees, which, in turn, is reflected in high financial costs (Terelak, 2008). Schmidt pointed out that in research into occupational stress, what is more and more frequently emphasized is the significance of organizational factors, which, in turn, is reflected in treating work as a system of social relationships (Schmidt, 2007).

\section{OCCUPATIONAL STRESS IN THE WORK OF A COURT PROBATION OFFICER}

Psychosocial threats may influence both mental and somatic health, directly or indirectly, by means of the influence exerted by stress. The greatest amount of attention has been devoted to the indirect consequences of such threats, mediated by the influence exerted by stress. Situations connected with work are felt to be stressful when the requirements connected with them are perceived by employees as not adjusted to the knowledge and abilities (competencies) possessed by them, or to their needs; in particular, that is the case for situations in which employees' level of control over work is low, and in which they receive insufficient support at the workplace (Cox, Griffiths, \& Rial-González, 2006). The most recent definition of stress, presented in the theory of Lazarus, is known as the controversial aspect of it by means of identifying a stress with a danger, and also reducing the psychological mechanism of assessment to anticipation, and also a failure to appreciate the influence exerted upon that assessment by motivations and emotions (Terelak, 2008).

Depending on the described processes of assessments, an individual experiences certain emotions, the force of which determines the level of stress in the course of the first phases of the occurrence of it. Emotional excitation is a factor triggering the immediate reactions of an individual, which include: involuntary reactions - changes in physiological processes (the release of stress hormones, tonicity, heart rate, etc.); changes in psychological processes (perception, thinking, making decisions, remembering); changes in behaviour (use of psychedelics, excessive eating, etc.), and also a conscious mental process, resulting in determining the ways of coping. Referring to that kind of reactions, researchers 
(similarly to Lazarus and Folkman) apply the name of secondary assessment, the final stage of which is the choice of one, or several, ways of reducing stress (coping). The selection of positive ways brings about minimization of stress tension and the occurrence of particular results (increased competence, satisfaction and positive image of the self). In turn, inadequate methods lead to high levels of felt stress, disorders of somatic and mental health, and inappropriate attitudes and motivations, for example, the feeling of helplessness. Research also differentiates the modifiers of stress, which depend on two aspects: the traits of an individual and social support. The former encompass the following: personality traits, the state of health, and the position in the structure of society. The latter group of modifiers encompasses two kinds of social support: potential and perceived. The process of stress, constructed in such a way, constitutes the foundation of developing the model of protecting the health of employees against the detrimental influence exerted by psychosocial factors; for that very reason, I considered it to be significant to describe the way in which that mechanism works in brief (Dudek, Waszkowska, Merecz, \& Hanke, 1999). Ogińska-Bulik emphasized that issues relevant to occupational stress have for several years been the subject of the substantial interest of researchers. They are brought about, first and foremost, by the increasing costs resulting from the influence exerted by stress, and incurred both by employees themselves and by organizations employing them, and also by the progressively increasing expenditure of the state related to the absences of employees and medical conditions constituting the result of stress being experienced (Ogińska-Bulik, 2006). Ogińska-Bulik reports that the work itself may be the source of stress, and occupational stress is the stress experienced at the place at which work is performed; it is, first and foremost, professions in human services, which involve intensive relationships with other people, and also in becoming involved in their problems, that are considered to be causing a substantial burden (Ogińska-Bulik, 2006).

Endler and Parker developed a questionnaire for investigating the styles of coping with stress, drawing inspiration from the transactional model of stress as it was presented by Lazarus; however, they base their conceptions on the interactive theoretical model of that researcher. In accordance with the opinion of those authors, remedial actions which are undertaken by an individual in a particular stress-inducing situation are the result of interaction which occurs between the qualities of that situation and the style of coping, peculiar to a given individual. I therefore define the styles of coping with stress in accordance with the classification by Endler and Parker (1992). Lazarus proposed two ways of coping - oriented on a task or on solving a problem, and coping concentrated on decreasing the level of emotional tension
(Lazarus, 1993). Parker and Endler added a third form of behaviour in stress-inducing situations, which is avoidance. As a consequence, they proposed the following categorization:

- the style concentrated on a task - it consists in taking action the objective of which is to solve a problem or to change the existing stress-inducing situation; it differentiates between the entire population and individuals who make efforts the objective of which is to solve a problem by means of taking advantage of cognitive processes;

- the style concentrated on emotions - it is typical in the case of individuals who prefer wishful thinking and fantasizing to taking effective and rational actions; the objective of the former is to eliminate a stress stimulus, or minimize it. This style is typical in the case of individuals manifesting propensities for concentrating on themselves, on their own emotional experiences, such as anger, tension or the feeling of guilt;

- the style concentrated on avoidance - typical in the case of individuals who tend to avoid experiencing or thinking about stress-inducing situations.

That is further classified into two forms of coping with stress: becoming involved in displacement activities (for example, shopping, excessive consumption of food, watching television, thinking about something pleasant, etc.), and seeking social interactions (Parker \& Endler, 1992; Strelau, Jaworowska, Wrześniewski, \& Szczepaniak, 2005). The authors of the Polish adaptation of this questionnaire (CISS) report that the state of stress and coping with stress constitute phenomena that are inseparable from one another. It has been proved by research that effective coping by means of the balanced adjustments of requirements and abilities leads to a reduction of stress, whereas ineffective coping in stress-inducing situations leads to progression of the level of stress being felt. The studies based on the understanding of coping as a style (a trait) aim to enable identification of individuals with inadequate resources to cope in stress-inducing situations. The indicated task implies the important practical significance in the form of it being possible to identify individuals threatened with the consequences of occupational stress, and it makes it possible to develop a system of prophylaxis for the entire occupational group, as well as indicating significant aspects of the procedure of selection (Strelau et al., 2005).

\section{OBJECTIVES OF RESEARCH}

The objective of this research is to identify the differences in the functioning of court probation officers the level of stress of whom is both low and high, within the scope of style of coping with stress, and to determine mutual correlations between the sub- 
jective feeling of occupational stress and the styles of coping with stress. The results of this research are presented in several stages which take into consideration the objectives referred to above. They are composed of:

1. Analysis of the general level of felt occupational stress, and the dimensions of it, being subjectively experienced by court probation officers, and identifying the sources of it at the workplace.

2. A detailed inquiry in terms of organizational, demographic and psychological factors, determining occupational stress.

3. Analysis of the selection of the style of coping with stress manifested by court probation officers with different levels of organizational stress.

\section{PARTICIPANTS AND PROCEDURE}

Research into the determinants of the occupational stress of court probation officers was conducted in two stages: I - pilot study, II - main study. The objective of the pilot study in question was to construct the research tool measuring the level and potential dimensions of occupational stress of professional court probation officers. The main study was conducted at the offices of the teams of the Court Probation Service. The teams of the Court Probation Service are part of the structure of the following 9, randomly selected, district courts (DCs): DC Wrocław, DC Bydgoszcz, DC Szczecin, DC Poznań, DC Łódź, DC Lublin, DC Kraków, DC Katowice and DC Białystok. Participation in the research was voluntary and anonymous; the tools were arranged in sets, and the order of those sets was random. The sets of research tools were received by 1,000 individuals altogether. The number of returned tools was 602 sets. After detailed analysis, 212 sets were rejected in connection with various formal shortcomings, for example, incompletely filled-in questionnaire, or answers conclusively suggesting their accidental character. For the statistical analysis, 390 completely filled-in sets of the nationwide randomly selected representative group of court probation officers were used. Table 1 contains a detailed description of the study group taking into consideration the number of participants and the composition of their group expressed in per cent.

Women constituted the overwhelming majority (74\%) of the participants in the research, which reflects the actual situation for individuals employed as court probation officers. The statistical analyses of the state of court probation personnel, and also the research conducted by the Institute of Justice, confirm that the majority of court probation officers in Poland are female $(80 \%)$. Amongst professional court probation officers in charge of adult individuals, every fourth one was male. Amongst court probation officers in charge of the family, every sixth one was male (Wójcik, 2010). The results of research conducted in $10 \mathrm{mem}-$ ber states of the European Union indicate that minor medical problems resulting from occupational stress affect females more frequently than males. Psychosocial problems, and also issues connected with mental health at the workplace, were found to be a priority in the internal politics of the states participating in the research (Świderski, 2006). Czapiński noted that females experience a greater number of somatic symptoms of stress, whereas stress afflicts males to a greater degree (Czapiński \& Panek, 2011). The largest group (43\%) of the studied individuals is that at the age range between 38 and 48 years. Furthermore, $20 \%$ of the participants are between 49 and 64 years old. The research conducted by the Institute of Justice indicates the age range of Polish court probation officers as between 24 and 75 . The average age is 41 . In the research, it was also emphasized that the length of service in the capacity of a court probation officer was diverse. Individuals who had only just commenced their career in the field were found to have worked for approximately one month, whereas those who have been working as court probation officers for at least 26 years may be considered to be experienced (Wójcik, 2010). What is worth pointing out is the specific tendency in terms of age, consisting in the aging of the occupational group being studied. That may bring about the accumulation of the felt consequences of occupational stress in a significant proportion of court probation officers. It is also an interesting area of research because, for the time being, industrial and organizational psychology focuses its interest on senior employees, whose period of occupation is going to end soon, i.e. those aged between 50 and 65 . The most important stressors in that period include the following ones: the necessity to cope with new technology, being stuck in a dead-end job, decreased psychomotor performance, the necessity to improve qualifications, discrimination, and problems related to the financial situation and the state of health (Widerszal-Bazyl, 2002). Czapiński confirmed the significance of age in the research conducted by himself and relevant to the measurement of the intensity of the subjective feeling of stress amongst Poles (Czapiński \& Panek, 2011). In the psychological literature, the issue of the connection between the age of an employee and their affection at the workplace and satisfaction is one of the frequently raised questions. The research made it clear that the connection between age and affection at the workplace assumes the form of a curve, which means that individuals commencing their occupational career enjoy good affection, which is subsequently decreased, and afterwards increased anew. Widerszal-Bazyl reports that after the $36^{\text {th }}$ year of life satisfaction with work increases simultaneously with the passage of time, and for that very reason, in the groups of older employees it is at a high level. 
Table 1

Socio-demographic and organizational description of the studied group

\begin{tabular}{|c|c|c|c|}
\hline Variables & & $N$ & $\%$ \\
\hline \multirow{2}{*}{ Sex } & female & 289 & 74 \\
\hline & male & 101 & 26 \\
\hline \multirow{3}{*}{ Age } & $23-37$ & 145 & 37 \\
\hline & $38-48$ & 168 & 43 \\
\hline & $49-64$ & 77 & 20 \\
\hline \multirow{2}{*}{$\begin{array}{l}\text { Kind of decisions } \\
\text { being carried out }\end{array}$} & criminal cases & 219 & 56 \\
\hline & family cases and cases involving juveniles & 171 & 44 \\
\hline \multirow{3}{*}{$\begin{array}{l}\text { Length of service } \\
\text { as a court proba- } \\
\text { tion officer }\end{array}$} & $1-14$ & 259 & 67 \\
\hline & $15-25$ & 119 & 30 \\
\hline & $26-40$ & 12 & 3 \\
\hline \multirow{4}{*}{ Occupational title } & voluntary court probation officer & 157 & 40 \\
\hline & professional court probation officer & 76 & 20 \\
\hline & senior professional court probation officer & 52 & 13 \\
\hline & specialized court probation officer & 105 & 27 \\
\hline \multirow{4}{*}{ Marital status } & single & 71 & 17 \\
\hline & married & 299 & 78 \\
\hline & widow/widower & 8 & 2 \\
\hline & divorced & 12 & 3 \\
\hline \multirow{3}{*}{ Education } & secondary & 41 & 10 \\
\hline & tertiary (B.A.) & 19 & 5 \\
\hline & tertiary (M.A.) & 330 & 85 \\
\hline \multirow{3}{*}{$\begin{array}{l}\text { Religious convic- } \\
\text { tions }\end{array}$} & practising Christian & 278 & 71 \\
\hline & non-practising Christian & 90 & 23 \\
\hline & atheist & 22 & 6 \\
\hline
\end{tabular}

Requirements at the workplace also determine the level of stress felt by employees, and, as it is verified by research, in that situation it is older employees who perceive their requirements at the workplace as lower than the younger ones do (Widerszal-Bazyl, 2008). The research was participated in by a greater number of court probation officers in charge of adult individuals (56\%), which is reflected, as well, in the proportion of them to the total number of court probation officers. Court probation officers in charge of the family constituted $44 \%$ of all the studied individuals. The largest group, amounting to $67 \%$, amongst the participants in the research, had been court probation officers for a short period of time only. Such a situation takes into consideration the direction of planned research because a particularly high level of susceptibility to occupational stress is manifested by individuals whose traits include being young, having worked for a short period of time only, a low level of education or limited occupational experience, commitment to work-related issues, and striving to be successful at work, simultaneously with a high level of aspirations, and also impatience, being hasty and competing against other people (OIP, 2012). In the model of court probation service being studied, three occupational titles were categorized: a professional court probation officer (20\%), a senior professional court probation officer (13\%), and a specialized court probation officer (27\%). Furthermore, a group of voluntary court probation officers, who cannot receive promotion in connection with the voluntary character of their service (40\%), was classified. Describing stress-triggering factors at the workplace, Łoboda paid attention to the stressors connected with professional development, which may be significant in the case of court probation officers in connection with the 
restricted opportunities of promotion and permanent organizational changes. The group of those stressors includes being dissatisfied with the course of one's career, the lack of prospects of further professional development, and the lack of the sense of job security (Łoboda, 1990). Definitely the largest number of court probation officers are in a formal marital relationship, whereas merely $3 \%$ of them have had negative experience in the form of the disintegration of a marital relationship. The research proves that living in a marital relationship may, for example, constitute a factor of special preventive significance in terms of reducing the risk of the occurrence of post-traumatic stress, the occurrence of which is likely in the specific working conditions of court probation officers (for example, in the milieu of their wards) (Corneil, Beaton, Murphy, Johnson, \& Pike, 1999). In turn, Czapiński adopts the assumption that a factor reducing the feeling of stress may be widowhood or being single (Czapiński \& Panek, 2011). The majority of the research participants had received tertiary education at M.A. level (85\% of them), whereas only a small group of them had not progressed beyond the level of secondary education as far as professional and voluntary court probation officers. In the context of the research into correlations between education and the level of felt stress, it is worth adding that in Poland a little fewer than $55 \%$ of individuals consider their lives to be stressful, whereas $35 \%$ of them mention stress as one of the factors responsible for the medical conditions of the cardiovascular system, which afflict them personally. Simultaneously, the percentage of individuals who declare that they experience stress increases together with the level of their education (TNS OBOP, 2008).

\section{TOOLS}

The Coping Inventory for Stressful Situations (CISS), the authors of which are N. S. Endler and J. D. A. Parker, with the Polish adaptation by J. Strelau, K. Wrześniewski, P. Szczepaniak (Strelau et al., 2005). The CISS is composed of 48 statements relevant to various behaviours, which individuals may undertake in stressinducing situations. The studied individual determines, with the application of a five-degree scale, the frequency with which they undertake a given activity in difficult and stress-inducing situations. The results are presented with the application of three scales:

1. SC(u)T - style concentrated on a task. Individuals receiving high results on that scale undertake in stress-inducing situations efforts the objective of which is to solve a problem by means of cognitive transformations, or attempting to change the situation.

2. $\mathrm{SC}(\mathrm{u}) \mathrm{E}$ - style concentrated on emotions is typical in the case of individuals who in stress-inducing situations manifest the propensity for concentrat- ing on themselves and focusing on their own emotions (anger, the feeling of guilt, tension).

3. SC(u)A - style concentrated on avoidance is typical in the case of individuals who in stress-inducing situations manifest attitudes the objective of which is to avoid thinking about and experiencing stress-inducing situations. SC(u)A may be observed in either of two forms: I(i)DA - involvement in displacement activities; and SSI - seeking social interactions. That tool is applied for the purpose of research and connected with practical needs, for example, as a tool in the recruitment processes in the case of certain positions in particular jobs (for example, police officers, fire brigade officers and soldiers) (Strelau et al., 2005).

The Probation Officer's Stress Questionnaire (POSQ) was developed by the author himself. That tool was developed to meet the needs of research to measure the level of felt stress. Due to its advantages, the tool may also be applied for research into organizational stress in the case of employees of educational and resocialization institutions. In order to separate the scales of the items of the questionnaire for the measurement of the level of stress of court probation officers, principal component analysis was conducted with the application of the Oblimin rotation, which permits the mutual correlation of factors. The Probation Officer's Stress Questionnaire has a high value of the reliability coefficient $(\alpha-.82)$, and it is applied for the purpose of individual or collective assessment of the level of felt occupational stress of court probation officers (professional and voluntary) being experienced by them at the workplace. Results represent the following norms: low, average and high. The presented method makes it possible to determine the general assessment of the feeling of stress, and it also separates the factors which are felt by the studied individuals as the most stress-triggering. These factors include the following: factor $1(\alpha-.94)$ - Contacts with wards; factor $2(\alpha-.92)$ - The feeling of dissatisfaction with work; factor $3(\alpha-.81)$ - Structure of the management of court probation officers; factor 4 $(\alpha-.79)$ - Organizational encumbrances; factor 5 $(\alpha-.83)-$ Collaboration with the court of law. This questionnaire is composed of 56 statements. Particular answers have been assigned numerical values (from 1 to 5 ), which appropriately determine the degree of felt stress next to each statement.

On the basis of the conducted research, the analyses of obtained results was conducted.

\section{DATA ANALYSIS}

The obtained data reveal an interesting correlation between the style of coping and the level of occupational stress. To achieve this objective, descriptive statistical data were collected, and to determine 
the significance of differences between the means, principally the methods of statistical analyses such as ANOVA and Student's $t$-test were applied. The strength of the connection between the variables being studied was determined based on Pearson correlation coefficients. As the border level of significance, the value of $p=.050$ was adopted. For the level of significance lower than .050 , it was considered that the difference between the groups being studied or variables is significant. In the research, the analysis of regression was also applied in order to study connections between variables and explain the significance of particular variables in the development of occupational stress. For the purpose of statistical calculations, SPSS 20.0 PL for Windows was applied.

\section{RESULTS}

The conducted research confirmed the need to verify the significance of the feeling of occupational stress of court probation officers at the workplace and the correlations between it and a number of variables. Below, I present statistical analyses which are relevant to the various aspects of occupational stress experienced in the studied group, and which encompassed the correlations between the general level of occupational stress and the dimensions of it, and organizational predictors (Wirkus, 2015).

Table 2 presents the difference between professional and voluntary court probation officers as far as the felt occupational stress is concerned, and within the framework of the compulsory model of probation service.

The obtained results indicate that the type of probation conclusively differentiates the exacerbation of occupational stress, which confirms the greater felt stress-inducing character in the dimension of work of professional court probation officers (in accordance with statutory norms, voluntary court probation officers may conduct no more than 10 cases, whereas professional court probation officers are in charge of between two and ten as many, or even more, cases, and also perform numerous additional tasks). Professional court probation officers manifest the strongest feeling of stress in the following dimensions: contacts with wards, the structure of management of court probation officers, organizational encumbrances, and collaboration with the court of law. This group also obtains higher results in terms of the general level of felt stress compared to voluntary court probation officers. The latter manifest a stronger feeling of stress measured on the scale of contacts with wards and collaboration with the court of law, which is likely to result from the fact that the work of a voluntary court probation officer is frequently only an additional occupation of a voluntary character. The scale of collaboration with the court of law is stress-inducing for both groups, but it is definitely more frequently so in the case of professional court probation officers, which is strange because court probation officers work for the court of law and are a part of the system of the justice system. The quoted interpretation suggests that it is necessary to consid-

Table 2

Exacerbation of occupational stress related to the model of court probation service

\begin{tabular}{|c|c|c|c|c|c|c|}
\hline \multirow[t]{2}{*}{ Scales of CISS } & \multicolumn{2}{|c|}{$\begin{array}{c}\text { Professional court probation } \\
\text { officers }\end{array}$} & \multicolumn{2}{|c|}{$\begin{array}{c}\text { Voluntary court probation } \\
\text { officers }\end{array}$} & \multirow[t]{2}{*}{$t$} & \multirow[t]{2}{*}{$p$} \\
\hline & $M$ & $S D$ & $M$ & $S D$ & & \\
\hline $\begin{array}{l}\text { Contacts with } \\
\text { wards }\end{array}$ & 2.90 & 0.68 & 2.68 & 0.82 & 2.17 & .005 \\
\hline $\begin{array}{l}\text { The feeling of dis- } \\
\text { satisfaction } \\
\text { with work }\end{array}$ & 2.87 & 0.76 & 2.40 & 0.73 & 0.55 & $<.001$ \\
\hline $\begin{array}{l}\text { Structure of the } \\
\text { management of } \\
\text { court probation } \\
\text { officers }\end{array}$ & 2.41 & 0.95 & 1.77 & 0.63 & 22.88 & $<.001$ \\
\hline $\begin{array}{l}\text { Organizational en- } \\
\text { cumbrances }\end{array}$ & 3.32 & 0.85 & 2.40 & 0.89 & 0.25 & $<.001$ \\
\hline $\begin{array}{l}\text { Collaboration with } \\
\text { the court of law }\end{array}$ & 3.08 & 1.02 & 2.54 & 1.03 & 0.00 & $<.001$ \\
\hline $\begin{array}{l}\text { General level of felt } \\
\text { stress }\end{array}$ & 14.12 & 3.60 & 11.27 & 3.49 & 0.61 & $<.001$ \\
\hline
\end{tabular}


Table 3

Exacerbation of occupational stress related to the kind of verdict enforcement

\begin{tabular}{|c|c|c|c|c|c|c|}
\hline \multirow[t]{2}{*}{ Scales of CISS } & \multicolumn{2}{|c|}{$\begin{array}{c}\text { Court probation officers for } \\
\text { adult individuals }\end{array}$} & \multicolumn{2}{|c|}{$\begin{array}{c}\text { Court probation officers in } \\
\text { charge of the family }\end{array}$} & \multirow[t]{2}{*}{$t$} & \multirow[t]{2}{*}{$p$} \\
\hline & $M$ & $S D$ & $M$ & $S D$ & & \\
\hline Contacts with wards & 2.75 & 0.72 & 2.89 & 0.78 & 0.56 & n.s. \\
\hline $\begin{array}{l}\text { The feeling of dis- } \\
\text { satisfaction } \\
\text { with work }\end{array}$ & 2.58 & 0.76 & 2.82 & 0.79 & 0.17 & .004 \\
\hline $\begin{array}{l}\text { Structure of the } \\
\text { management of } \\
\text { court probation } \\
\text { officers }\end{array}$ & 2.17 & 0.91 & 2.15 & 0.88 & 0.06 & n.s. \\
\hline $\begin{array}{l}\text { Organizational en- } \\
\text { cumbrances }\end{array}$ & 2.89 & 1.05 & 3.02 & 0.88 & 12.27 & n.s. \\
\hline $\begin{array}{l}\text { Collaboration with } \\
\text { the court of law }\end{array}$ & 2.88 & 1.04 & 2.85 & 1.07 & 0.55 & n.s. \\
\hline $\begin{array}{l}\text { General level of felt } \\
\text { stress }\end{array}$ & 12.76 & 3.96 & 13.27 & 3.63 & 1.39 & n.s. \\
\hline
\end{tabular}

er modifications in the scope of currently existing structures of the functioning of the Court Probation Service within the frameworks of the court of law. The research into the occupational stress of Kuziora, conducted on a group of voluntary court probation officers carrying out decisions in criminal cases, indicates the principal determinants of the occurrence of occupational stress. These factors include the lack of adequate gratification for the performed tasks, the lack of social support, and difficulties in working with wards (Kuziora, 2010). However, it is not a negative assessment of the effectiveness of their work, because the research of Gogacz proves that voluntary court probation officers are able to maintain adequate psychological distance in relationships with wards, which also results from the appropriate selection of educational measures (Gogacz, 2010). It is worth pointing out that, in spite of conducting a given case by a voluntary court probation officer, it is a professional court probation officer who is responsible for it. If it transpires that irregularities are discovered, it is the latter who faces legal consequences. In Table 3, the differences between groups implementing different kinds of decisions are presented.

The most differentiating stressor is the feeling of dissatisfaction with work, which dominates in the case of court probation officers in charge of the family. The results obtained in the remaining dimensions are similar, which confirms that the phenomenon of occupational stress is relevant to, to a similar degree, the court probation officers of both specializations in the court probation service. The figure below presents the results in terms of the general level of stress ex- perienced in the studied groups. The majority of court probation officers experience an average feeling of occupational stress, which is an alarming situation in the dimension of the diagnosis of the state of the court probation service. The high level of the exacerbation of felt stress in groups being compared brings about serious consequences, including in the form of occupational burnout syndrome. Court probation officers in charge of the family frequently manifest the highest level of occupational stress index (19\%) in comparison with the group of court probation officers in charge of adult individuals (15\%) (Figure 1).

The data in Table 4 present the differences between groups, related to the occupational title and the scales of the CISS.

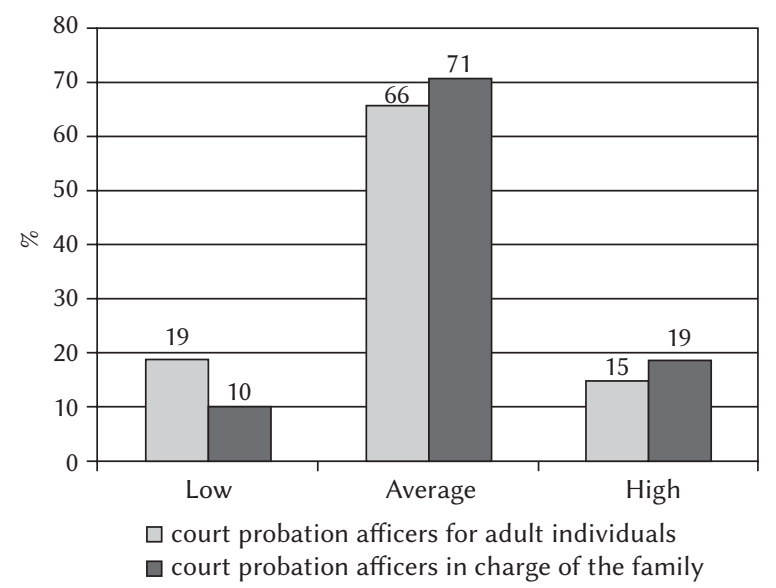

Figure 1. Feeling of occupational stress of court probation officers and the kind of verdict enforcement. 
Table 4

Exacerbation of occupational stress related to occupational title

\begin{tabular}{|c|c|c|c|c|c|}
\hline \multirow[t]{2}{*}{ Scales of CISS } & $\begin{array}{c}\text { Professional court } \\
\text { probation officer }\end{array}$ & $\begin{array}{c}\text { Senior profession- } \\
\text { al court probation } \\
\text { officer }\end{array}$ & $\begin{array}{l}\text { Specialized court } \\
\text { probation officer }\end{array}$ & \multirow[t]{2}{*}{$\chi^{2}$} & \multirow[t]{2}{*}{$p$} \\
\hline & Average of ranks & Average of ranks & Average of ranks & & \\
\hline $\begin{array}{l}\text { Contacts } \\
\text { with wards }\end{array}$ & 99.30 & 112.66 & 119.57 & 4.22 & n.s. \\
\hline $\begin{array}{l}\text { The feeling of dissat- } \\
\text { isfaction with work }\end{array}$ & 91.02 & 118.48 & 118.22 & 9.22 & .010 \\
\hline $\begin{array}{l}\text { Structure of the } \\
\text { management of court } \\
\text { probation officers }\end{array}$ & 110.51 & 113.04 & 121.36 & 1.29 & n.s. \\
\hline $\begin{array}{l}\text { Organizational } \\
\text { encumbrances }\end{array}$ & 113.15 & 122.60 & 111.58 & 0.99 & n.s. \\
\hline $\begin{array}{l}\text { Collaboration } \\
\text { with the court of law }\end{array}$ & 108.65 & 108.31 & 124.99 & 3.51 & n.s. \\
\hline $\begin{array}{l}\text { General level of felt } \\
\text { stress }\end{array}$ & 106.99 & 114.15 & 125.66 & 3.50 & n.s. \\
\hline
\end{tabular}

The general index of felt occupational stress does not differentiate categories being analyzed and related to the occupational title, even though the exacerbation of occupational stress increases noticeably as one achieves promotion to a higher position. The factor differentiating the groups is the feeling of dissatisfaction with one's occupation. That feeling increases as one achieves promotion to higher positions. A good solution leading to minimizing the stress-inducing character connected with dissatisfaction with work is broadening the opportunities of promotion and the modification of the names applied to the consecutive occupational titles. A specialized court probation officer in the structures of the Court Probation Service may eventually hope to achieve nothing more than the position of the head of a team; in that case, the term of service is not regulated by relevant legal provisions in any way whatsoever. At this moment, what is worth emphasizing is the result of positive occupational adaptation, which consists in the adjustment of an individual and their working environment. Schneider, Smith, Taylor, and Fleenor (1998) apply the term homogeneity. A good adjustment occurs when the working environment is capable of providing the means of fulfilling needs being sought by an individual, and when that individual is able to manifest the abilities needed in that milieu (Dawis, 2000). If we are looking at the lack of adjustment, there may occur a dissonance between an employee and an organization, which may eventually be likely to bring about the feeling of dissatisfaction with work, conflicts between roles, occupational stress, or staff turnover. The functionaries of the
Prison Service, who were the subject of the research conducted by Piotrowski as well, perceive their own work as very stressful. The employees of the penitentiary system declare (similarly to court probation officers) that they feel a substantial encumbrance with their occupational responsibilities, and that they do not feel satisfied with work. The studied individuals perceive the style of management of a penitentiary facility as inappropriate, and contacts with those serving sentences is a source of mental encumbrances for them as well (Piotrowski, 2010).

Maslach and Leiter indicate the complexity of social problems (making the European labour market much more complex), which exert a direct influence on the quality of work, writing that whereas stagnation in the economy in the situation in which reductions of personnel observable everywhere have decreased the opportunities of finding a different job, individuals are inclined to work in conditions not fulfilling their expectations - and that just to survive (Maslach \& Leiter, 2011).

In Figure 2, the problem of the occupational stress of court probation officers manifesting average results on the scale of occupational stress, and an increase in the number of those experiencing the highest level of occupational stress simultaneously with being promoted to a higher occupational title, is clearly presented. It confirms that it is inappropriate to motivate employees by means of the structure of promotions (already succinctly mentioned before).

In Table 5, the correlations between the general level of occupational stress and the dimensions of it with the length of service are presented. That vari- 
able differentiates groups in every dimension, apart from that of organizational encumbrances. The analysis of the mean indicates that, in spite of acquired professional and practical life experience, the general level of the felt stress and the dimensions of it increases, which clearly shows the negative results of one's current occupation.

The results depict increasing occupational stress in spite of achieving promotion to higher positions and improving qualifications. That is a specific situation because greater professional experience ought to, in principle, exert a minimizing influence on the felt stress, in particular in the following dimensions: contacts with wards and the structure of management of court probation officers. That may be connected with the dynamic changes in law, which are accompanied by ever more numerous responsibilities of the studied group of employees, but also emphasizes the effectiveness of the actions being conducted. The lack of specialization is becoming a more and more serious problem within the scope of working with the specific group(s) of convicted individuals, for example, with those who manifest mental disorders. Frequently, the wards of the court of law manifesting unpredictable behaviours in social interactions are commonly referred to as psychos or psychopaths, and, as it is manifested by practice, resorting to that kind of nomenclature is not an accident. As it was reported by Pastwa-Wojciechowska, psychopathy as a personality disorder is one of those problems which are most frequently raised in the penitentiary milieu. Pastwa-Wojciechowska quotes numerous conceptions and develops various definitions which not only are useful in the realm of the practice of serving a prison sentence in the conditions of not retaining

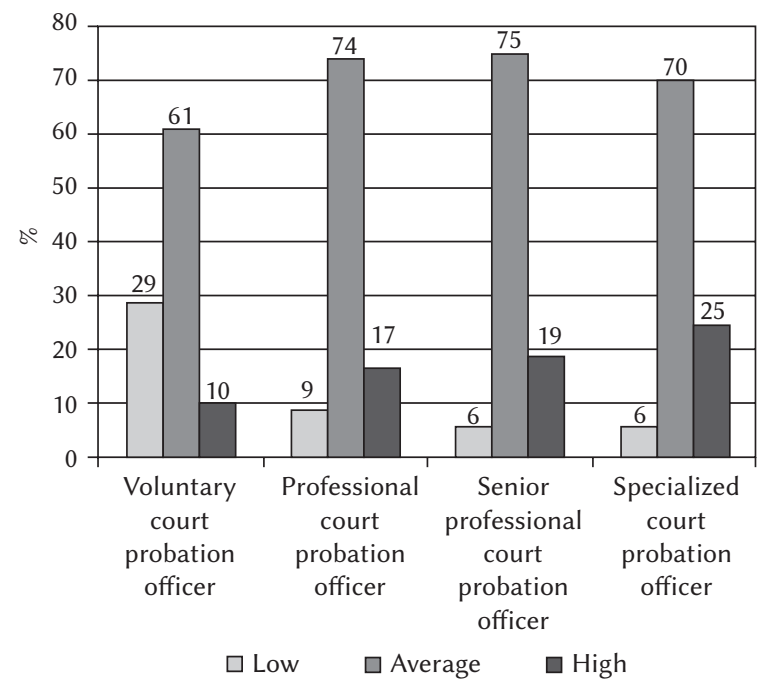

Figure 2. Feeling of occupational stress of court probation officers and the occupation.

freedom in conditions of isolation in a penitentiary institution, but which also constitute valuable implications for working with convicted individuals who retain their freedom, and who are under supervision conducted by a court probation officer (Pastwa-Wojciechowska, 2008).

In Table 6, the collation of differences between the groups of court probation officers manifesting low and high levels of occupational stress and the style of coping is presented.

The style concentrated on a task does not differentiate the two groups significantly, whereas the style concentrated on emotions, which is relevant to the style typical of individuals who tend to concentrate

Table 5

Exacerbation of occupational stress related to the length of service as a court probation officer

\begin{tabular}{|c|c|c|c|c|c|}
\hline \multirow[t]{2}{*}{ Scales of CISS } & $\begin{array}{l}\text { 1-14 years of } \\
\text { service }\end{array}$ & $\begin{array}{l}\text { 15-25 years of } \\
\text { service }\end{array}$ & $\begin{array}{l}\text { 26-40 years of } \\
\text { service }\end{array}$ & $\chi^{2}$ & $p$ \\
\hline & Average of ranks & Average of ranks & Average of ranks & & \\
\hline Contacts with wards & 169.91 & 199.22 & 211.45 & 6.98 & .030 \\
\hline $\begin{array}{l}\text { The feeling of dissat- } \\
\text { isfaction with work }\end{array}$ & 165.73 & 207.97 & 226.09 & 14.24 & .001 \\
\hline $\begin{array}{l}\text { Structure of manage- } \\
\text { ment of court proba- } \\
\text { tion officers }\end{array}$ & 173.70 & 211.44 & 236.91 & 12.02 & .002 \\
\hline $\begin{array}{l}\text { Organizational en- } \\
\text { cumbrances }\end{array}$ & 177.78 & 201.04 & 218.23 & 4.66 & n.s. \\
\hline $\begin{array}{l}\text { Collaboration with } \\
\text { the court of law }\end{array}$ & 176.45 & 209.85 & 242.14 & 10.24 & .006 \\
\hline $\begin{array}{l}\text { General level of felt } \\
\text { stress }\end{array}$ & 179.07 & 211.65 & 251.73 & 10.38 & .006 \\
\hline
\end{tabular}


Table 6

Comparison of the means (M, SD) of the style of coping between the groups of court probation officers suffering from low and high levels of stress

\begin{tabular}{|c|c|c|c|c|c|c|}
\hline \multirow[t]{2}{*}{ Scales of CISS } & \multicolumn{2}{|c|}{$\begin{array}{l}\text { Suffering from } \\
\text { a low level of stress }\end{array}$} & \multicolumn{2}{|c|}{$\begin{array}{c}\text { Suffering from } \\
\text { a high level of stress }\end{array}$} & \multirow[t]{2}{*}{$t$} & \multirow[t]{2}{*}{$p$} \\
\hline & $M$ & $S D$ & $M$ & $S D$ & & \\
\hline $\begin{array}{l}\mathrm{SC}(\mathrm{u}) \mathrm{T}-\text { style concen- } \\
\text { trated on a task }\end{array}$ & 62.70 & 7.13 & 62.13 & 8.33 & 4.89 & n.s. \\
\hline $\begin{array}{l}\mathrm{SC}(\mathrm{u}) \mathrm{E}-\text { style concen- } \\
\text { trated on emotions }\end{array}$ & 33.69 & 7.48 & 45.16 & 9.15 & 2.44 & $<.001$ \\
\hline $\begin{array}{l}\mathrm{SC}(\mathrm{u}) \mathrm{A} \text { - style concen- } \\
\text { trated on avoidance } \\
\text { I(i)DA - involvement in } \\
\text { displacement activities }\end{array}$ & 16.02 & 4.52 & 19.32 & 4.77 & 0.07 & $<.001$ \\
\hline $\begin{array}{l}\mathrm{SC}(\mathrm{u}) \mathrm{A} \text { - style concen- } \\
\text { trated on avoidance } \\
\mathrm{SSI} \text { - seeking social inter- } \\
\text { actions }\end{array}$ & 16.48 & 3.79 & 18.37 & 4.29 & 0.26 & .002 \\
\hline
\end{tabular}

on themselves and their own emotional experiences, differentiates the studied groups the most. That group includes anger, the feeling of guilt and tension. Individuals manifesting that style show a propensity for wishful thinking and fantasizing, which may reduce the emotional tension connected with a stressful situation, but also sporadically influences the progression of stress being felt, and also the onset of the state of depression (Strelau et al., 2005). Individuals manifesting a high level of felt occupational stress with a significantly greater frequency select the style being described in comparison with individuals suffering from a low level of stress. The research conducted by Heszen-Niejodek also indicates that emotions exert an influence on the strategies of coping, which are the result of the remedial strategies being applied, and that they influence cognitive assessment, which constitutes a crucial element in the process of coping with stress. Simultaneously, it suggests that is recommendable to conduct further research into coping with stress, including in terms of individual factors (Heszen-Niejodek, 2004). Lazarus and Folkman report that the objective of coping concentrated on emotions is regulating emotional reactions triggered by a situation, whereas coping concentrated on a problem is directed towards taking the source of stress under control (Folkman \& Lazarus, 1980). The presented way of coping, which is preferred by the studied individuals, indicates the need to implement a general system of prophylaxis for the entire occupational group, but it also applied for the identification of individuals threatened with the possible negative consequences of stress at the workplace being experienced.

The style concentrated on avoidance, which is typical in the case of individuals who, when they are in a stressful situation, avoid experiencing that situation, and thinking about it, also significantly differentiates the groups being studied, and is typical in the case of stressed court probation officers. The style concentrated on avoidance assumes two forms: involvement in displacement activities, and seeking social interactions (Strelau et al., 2005). In both of those forms, court probation officers suffering from a high level of stress are significantly different from court probation officers suffering from a low level of stress. Heszen-Niejodek postulates that the description of the style of coping in informational-cognitive categories requires the application of the dimension responsible for the acquisition and taking advantage of information referred to as confrontation, and also the dimension referred to as avoidance and consisting in directing one's attention elsewhere. The author claims that the condition of initiating the process of coping with a medical problem (in view of the issue being studied - the consequences of occupational stress extended in time) is ascertaining the occurrence of the symptoms of that medical problem. The result of that process is dependent on the system of pro-health convictions and taking advantage of it in the practice of action. Heszen-Niejodek emphasized that the moderate application of the strategies of avoidance protects against an excessive concentration on one's own health, and the arising anxiety. The researcher quotes studies confirming the results which make it clear that individuals are capable, to a certain degree, of adjusting situational coping to the requirements of a situation regardless of the properties of the dispositional style of coping and indicates that, in controlled conditions, confrontational strategies are applied whereas in non-controlled conditions avoidance strategies 
are resorted to (Heszen-Niejodek, 2004). Guzowska indicates, on the basis of conducted research, that individuals whose major feature is the repressive style of coping will become involved in actions that serve to minimize emotional reactions. The reasons for such behaviour include the individual conviction that one is not susceptible to negative emotions, and also conscious manifestation of exerting control over emotions. The author quotes numerous examples of scientific research indicating that excessive inhibition or suppression of emotions is connected with negative health effects, in terms of both psychology and the somatic state of health. Furthermore, she reports that the connection between the repressive style of coping and health is significant in connection with the deteriorated activity of the immune system, or in connection with neoplasms, and also with the conditions of the cardiovascular system (Guzowska, 2004). The selection of the adequate style of coping by the studied court probation officers is significant for the broadly understood notion of the quality of life. The influence exerted by coping and stress on the quality of life emphasizes the way of viewing the quality of life as a function of the resourcefulness of an individual. In that conception, the ability to cope in a threatening situation may be conducive to the improvement of affection and the quality of life. The research conducted hitherto suggests that in connections between stress and the quality of life differences relevant to the application by different individuals of various styles of coping in those same situations of real life are significant. For that very reason, the influence exerted by stress on the quality of life also modifies varied effectiveness of taking advantage of own resources in coping (Ratajczak, 2005; Zalewska, 2003).

Afterwards, the analysis of linear regression was conducted; in that, the dependent variable was constituted by the general result of felt occupational stress and the following predictors: $\mathrm{SC}(\mathrm{u}) \mathrm{T}$ - style concentrated on a task, SC $(\mathrm{u}) \mathrm{E}$ - style concentrated on emotions, SC(u)A - style concentrated on avoidance by means of I(i)DA - involvement in displacement activities, and SSI - seeking social interactions.
The developed model contains five predictors and explains $34 \%$ of the variance of the dependent variable (corrected $R$-square was found to be .34). The model was well adjusted to the data: $F(5,331)=24.08$, $p<.001$. The obtained coefficients of regression are presented in Table 7.

As it can be concluded from the obtained results, the general result of occupational stress is under the strongest influence of style concentrated on emotions. These results are in accordance with the available research. Concentration on emotions is the principal factor generating occupational stress, the consequence of which may include professional burnout syndrome and different disorders of the state of health.

\section{DISCUSSION}

The research confirms a significant influence exerted by organizational determinants on the general level of felt occupational stress. Professional court probation officers experience a higher level of felt occupational stress; what is conducive to that is high encumbrance with occupational responsibilities, and also functioning directly in structures of the court of law. It is also noticeable that there occurs a significant influence exerted by the occupational title, the attaining of which is dependent upon, first and foremost, having served for a sufficient period of time. Occupational titles offer a very restricted prospect of development, which makes it impossible for the supervisory bodies to use them as a source of actual motivation, and also practically results in a natural decrease in creative professional potential. Tecław and Nowosielski, based on research conducted on dispositional groups (the municipal police, police, fire brigade and military units), established that the most important values in the organizational structures of them are the following: recognition for good results of work, the possibility of consulting one's decisions with their superiors, having a superior who is respected by the employees, and also the real opportunities of being promoted (Tecław \& Nowosielski, 2010). The

Table 7

Participation of styles of coping in explaining occupational stress

\begin{tabular}{lccccc}
\hline Scales of CISS & $B$ & $S E$ & $\beta$ & $t$ & $p$ \\
\hline Constant & 7.41 & 26.62 & & 0.28 & .781 \\
SC $(\mathrm{u}) \mathrm{T}$ - style concentrated on a task & 0.08 & 0.36 & .02 & 0.23 & .820 \\
SC (u)E - style concentrated on emotions & 2.33 & 0.30 & .54 & 7.89 & $<.001$ \\
SC (u)A - style concentrated on avoidance & & & & & .208 \\
I(i)DA - involvement in displacement activities & 0.81 & 0.64 & .09 & 1.26 & \\
SC(u)A - style concentrated on avoidance & & & & & .50 \\
SSI - seeking social interactions & 0.42 & 0.71 & .04 & 0.60 & .550 \\
\hline
\end{tabular}


results of my own research are also compatible with the research conducted in the probation services of the same kind which function in the USA and in Europe. Thomas presented the results of research into the occupational stress of court probation officers which reveal the most important causes of stress: unnecessary/redundant paperwork, having no time to complete the tasks with which one has been entrusted within the framework of the contract (which is the most frequently indicated cause of stress), financial problems, uncertainty related to retirement benefits, the insufficient sums provided as a return of the costs of performing tasks in the field, and family problems. Thomas also emphasized that several causes of stress deserved a more detailed analysis, and enumerated (among others) political pressures exerted at work, not being represented by trade unions, and dangers connected with the performance of occupational activities (Thomas, 1988), whereas the research conducted by Whisler established the following sources of stress at the workplace of court probation officers: an excessive amount of bureaucracy, low remuneration, the lack of opportunities of promotion, the leniency of the courts of law, conflicts at the workplace, the restricted possibility to make decisions, failure of superiors to appreciate employees, and the fact that achievements and outstanding commitment to work are not rewarded, as well as the failure of the managerial staff to provide support (Slate, Johnson, \& Wells, 2000). Slate, Wells and Johnson, conducting their research into organizational stress, investigated the way in which stress exerts a negative influence on the state of health of court probation officers. Their research revealed the fundamental factors constituting the principal determinants of occupational stress: remuneration inadequate for the activities performed at the workplace, the forgiving attitude of the court of law in relation to criminals, the lack of an individual approach towards a ward within the framework of systemic solutions, the high level of requirements of the effectiveness of activities to be ensured in a short period of time, the lack of social recognition for the profession, and the lack of resources to support a court probation officer in the organization of the process of the re-adaptation of the ward of the court of law (Slate, Wells, \& Johnson, 2003). Brown, who was analysing occupational stress in the context of the actions of the probation organization, indicated, first and foremost, the role of conflict, bureaucracy, problems in terms of interpersonal communication, and the lack of participatory management, as the principal determinants of the consequences of that in the form of professional burnout syndrome. Brown also proved the connection between stress and chronic medical conditions (Brown, 1987).

Some researchers report that the state of stress and coping with stress constitute phenomena which cannot be separated one from another (Strelau et al., 2005). Court probation officers suffering from a low level of stress and those suffering from a high level of stress are groups different from one another within the scope of the selection of style concentrated on emotions, which is relevant to the style typical in the case of individuals manifesting the propensity for concentration on themselves and their own emotional experiences. They include anger, the feeling of guilt and tension. Individuals manifesting that style manifest a propensity for wishful thinking and fantasizing, which may reduce emotional tension connected with a stressful situation, but which also exerts an influence on the progression of felt stress, as well as on the occurrence of the state of depression. Individuals manifesting a high level of felt occupational stress significantly more frequently than those suffering from a low level of stress select the style being described. The research conducted by Heszen-Niejodek also indicates that emotions influence the strategies of coping, which are the result of the remedial strategies being applied, and that they influence the cognitive assessment, which is the crucial element in the process of coping with stress. The correlation referred to above will also explain such a prominent influence exerted by psychological predictors. That is a serious problem for the studied occupational group because, as it was reported by Jakubowska-Winecka, individuals having a strong propensity for concentrating on a problem act in accordance with their own personality determinants, whereas individuals representing the style concentrated on emotions select strategies connected with the feeling of guilt, which means accepting responsibility and avoidance (JakubowskaWinecka, 2004). The selection of the appropriate style of coping by the studied court probation officers is of significance for the broadly understood quality of life. The influence exerted by coping and stress on the quality of life emphasizes the view of the quality of life as a function of the resourcefulness of an individual. The research conducted to date suggests that in connections between stress and the quality of life, there are significant differences relevant to the application by various individuals of different styles of coping in those same situations of real life (Ratajczak, 2005). The conducted linear regression analysis, in which the dependent variable was the general result for occupational stress predictors $(\mathrm{SC}(\mathrm{u}) \mathrm{T}$ - style concentrated on a task, SC(u)E - style concentrated on emotions, SC(u)A style concentrated on avoidance by means of I(i)DA - involvement in displacement activities, and SSI - seeking social interactions), made it possible to develop the ultimate model which contains five predictors, and explained $34 \%$ of the variance of the dependent variable (corrected $R$-square was found to equal .34). That proved a very interesting correlation between occupational stress and the styles of coping. Ogińska-Bulik reports 
that the extended occupational stress may, as a consequence, bring about changes in the various spheres of functioning of an individual, including changes in the emotional-cognitive sphere (anxiety, annoyance, deteriorated affection, depression, de-concentration, being dissatisfied with work, etc.), changes in behaviour (decreased efficiency, propensity for resorting to stimulants and the use of violence, etc.), minor medical problems and somatic diseases (Ogińska-Bulik, 2009).

\section{CONCLUSIONS}

The quality of the system of the prophylaxis of occupational stress and counteracting the negative consequences is evidenced by the broad spectrum of conditions which ought to be taken into consideration. These factors include psychological predictors, the abilities to function in social relationships, and demographic and organizational determinants within the scope of the work performed. The current system of the organization of the work of court probation officers fails to take into consideration the issues of occupational stress and the consequences of that, which may partly be remedied by means of implementing several proposed solutions:

- changing the model of social-professional court probation service into a cohesive and fully-professionalized one,

- developing a general model of professional selection fulfilling the rigours imposed by the Council of Europe in Rule 38 of the European Sanctions Policies and Alternative Measures, which emphasizes the need to develop the sanctioned selection of personnel in quantitative terms (increase in the number of jobs), and in qualitative ones (examining personality traits and different aspects of professional competence),

- providing specialist career counselling directed at the problems of employees in connection with the performed job and having its seat elsewhere than at the seat of the court of law available,

- organizing prophylactic campaigns devoted to occupational stress and creating a friendly working environment,

- promoting physical activity and the pursuit of personal interests, and motivating employees to participate in relaxation training sessions.

The research indicates that the co-participation of employees in making decisions clearly eases the occupational stress suffered by them, and significantly increases the level of their satisfaction with work (Slate \& Vogel, 1997; Slate, Vogel, \& Johnson, 2001; Slate, Wells, \& Johnson, 2003). Changes are relevant to managing and controlling attitudes in a traditional, autocratic ambience of an organization, into one which is helpful and consultative in relation to employees. The administrators of the justice system ought also to devote more attention and means to training the heads of the teams of court probation officers (Gonzales, Schofield, \& Hart, 2005). Eccles reports an example relevant to the implementation of organizational solutions which confirms that improvement in the scope of communication ought to be the first step towards coping with insufficient feedback, and the scarcity of knowledge relevant to performing work in a traditional, autocratic bureaucracy (Eccles, 1993).

\section{RefERENCES}

Brown, P.W. (1987). Probation officer burnout: An organizational disease/an organizational cure. Federal Probation, 51, 17-21. Retrieved from: http:// web.ebscohost.com.

Corneil, W., Beaton, R., Murphy, S., Johnson, C., \& Pike, K. (1999). Exposure to traumatic incidents and prevalence of posttraumatic stress symptomatology in urban firefighters in two countries. Journal of Occupational Health Psychology, 4, 131-141.

Cox, T., Griffiths, A., \& Rial-González, E. (2006). Badania nad stresem w pracy [Research on stress at work]. Luksemburg: Urząd Oficjalnych Publikacji Wspólnot Europejskich.

Czapiński, J., \& Panek T. (2011). Diagnoza spoteczna 2011. Warunki i jakość życia Polaków. Retrieved from: http://www.diagnoza.com/pliki/raporty/Diagnoza_raport_2011.pdf.

Dawis, R. V. (2000). Work adjustment theory. In: A. Kazdin (ed.), Encyclopedia of psychology (pp. 91-111). New York: Oxford University Press.

Dudek, B., Waszkowska, M., Merecz, D., \& Hanke, W. (1999). Ochrona zdrowia pracowników przed skutkami stresu zawodowego [Protecting employees' health against the effects of job stress]. Łódź: Instytut Medycyny Pracy.

Eccles, T. (1995). The Deceptive Allure of Empowerment. In: A. A. Thomson, A. J. Strickland, \& T. Robertson Kramer (eds.), Reading in Strategic Management (pp. 496-509). Chicago: Irwin.

Endler, N. S., \& Parker, J. D. A. (1992). Multidimensional assessment of coping: A critical evaluation. Journal of Personality and Social Psychology, 58, 844-854.

Folkmann, S., \& Lazarus, R. S. (1980). An analysis of doping in a middle - aged community sample. Journal of Health and Social Behaviour, 21, 219-239.

Gogacz, K. (2010). Obraz społecznych kuratorów sądowych dla dorosłych w percepcji dozorowanych [The image of social probation officers for adults in the perception of offenders]. In: Z. Bartkowicz, A. Węglińnki, \& A. Lewicka (eds.), Powinności i kompetencje w wychowaniu osób niedosto- 
sowanych spotecznie [Duties and competencies in educating socially maladjusted people]. Lublin: Wyd. UMCS.

Gonzales, A. R., Schofield, R. B., \& Hart, S. V. (2005). Stress among probation and parole officers and what can be done about it. In: Research for practice, US Department of Justice. Washington, DC: Department of Justice Office.

Guzowska, M. (2004). Represyjny styl radzenia sobie ze stresem a postawa wobec choroby u osób po zawale serca [Repressive style of stress management and attitude towards the illness after a heart attack]. In: K. Wrześniewski, \& D. Włodarczyk (eds.), Choroba niedokrwienna serca [Ischemic heart disease]. Gdańsk: Gdańskie Wydawnictwo Psychologiczne.

Heszen-Niejodek, I. (2004). Styl radzenia sobie ze stresem jako indywidualna zmienna wpływająca na funkcjonowanie w sytuacji stresowej [Stress management style as an individual variable that affects functioning in a stressful situation]. In: J. Strelau (ed.), Osobowość a ekstremalny stres [Personality and extreme stress]. Gdańsk: Gdańskie Wydawnictwo Psychologiczne.

Jakubowska-Winecka, A. (2004). Style a strategie radzenia sobie ze stresem po zawale serce [Styles and strategies of stress management after a heart attack]. In: K. Wrześniewski, \& D. Włodarczyk (eds.), Choroba niedokrwienna serca [Ischemic heart disease]. Gdańsk: Gdańskie Wydawnictwo Psychologiczne.

Kuziora, G. (2010). Analiza porównawcza stresu zawodowego społecznych kuratorów dla dorosłych oraz funkcjonariuszy służby więziennej [A comparative analysis of job stress of social probation officers for adults and prison officers]. Warszawa: Towarzystwo Przyjaciół Dzieci. Krajowy Komitet Wychowania Resocjalizującego im. Kazimierza Lisieckiego.

Lazarus, R. (1993). Coping theory and research: Past present and future. Psychosomatic Medicine, 55, 234-247.

Łoboda, M. (1990). Czynniki stresogenne w organizacji [Stressors in organization]. In: A. Biela (ed.), Stres $w$ pracy zawodowej. Wybrane zagadnienia [Stress in professional work. Selected aspects]. Lublin: Katolicki Uniwersytet Lubelski.

Maslach, C., \& Leiter, M. (2011). Prawda o wypaleniu zawodowym. Co zrobić ze stresem w organizacji? [The truth about professional burnout. What to do with stress in an organization]. Warszawa: Wydawnictwo Naukowe PWN.

Ogińska-Bulik, N. (2009). Stres zawodowy u policjantów. Źródła, konsekwencje, zapobieganie [Job stress in police officers. Sources, consequences, prevention]. Łódź: WSHE.

Ogińska-Bulik, N. (2006). Stres zawodowy w zawodach ustug społecznych. Źródta, konsekwencje, zapobieganie [Job stress in social services occupations. Sources, consequences, prevention]. Warszawa: Difin.

Okręgowy Inspektorat Pracy. (2012). Poradnik dla pracodawcy [Employer's Guide]. Retrieved from: http://www.lodz.oip.pl/stres_pliki/INFORMACJE\%20DOT.\%20STRESU.pdf.

Parker, J. D. A., \& Endler, N. S. (1992). Coping with coping assessment: A critical review. European Journal of Personality, 6, 321-344.

Pastwa-Wojciechowska, B. (2008). Znaczenie diagnozy psychopatii $w$ opiniowaniu psychologiczno-penitencjarnym [The meaning of psychopathy diagnosis in psycho-penitentiary assessment]. In: W. Ambrozik, H. Machel, \& P. Stępniak (eds.), Misja Stużby Więziennej a jej zadania wobec aktualnej polityki karnej i oczekiwań spotecznych [The mission of the Prison Service and its tasks in the view of the present penal policy and social desirabilities]. Poznań - Gdańsk - Warszawa - Kalisz: Centralny Ośrodek Szkolenia Służby Więziennej.

Piotrowski, A. (2010). Stres i wypalenie zawodowe funkcjonariuszy Stużby Więziennej [Stress and professional burnout of prison officers]. Warszawa: Difin.

Ratajczak, Z. (2005). Jakość życia człowieka w warunkach narastających zagrożeń [The quality of human life in the growingly dangerous circumstances]. In: M. Straś-Romanowska, K. Lachowicz-Tabaczek, \& A. Szmajke (eds.), Jakość życia w badaniach empirycznych i refleksji teoretycznej [The quality of life in empirical studies and theoretical reflection] (pp. 233-241). Warszawa: Kolokwia Psychologiczne.

Schmidt, K. H. (2007). Organizational commitment: A further moderator in the relationship between work stress and strain? International Journal of Stress Management, 14, 26-40.

Schneider, B., Smith, D. B., Taylor, S., \& Fleenor, J. (1998). Personality and organizations: a test of the homogenity of personality hypothesis. Journal of Applied Psychology, 83, 3.

Sęk, H. (2000). Wypalenie zawodowe u nauczycieli. Uwarunkowania i możliwości zapobiegania [Professional burnout of teachers. Determinants and prevention]. In: H. Sęk (ed.), Wypalenie zawodowe. Przyczyny, mechanizmy, zapobieganie [Professional burnout. Causes, mechanisms, prevention]. Warszawa: Wydawnictwo Naukowe PWN.

Slate, R. N., Wells T. L., \& Johnson W. W. (2003). Opening the Manager's Door: State Probation Officer Stress and Perceptions of Participation in Workplace Decision Making, 2003. Crime and Deliquency, 49, 519-541. Retrieved from: http://web. ebscohost.com.

Slate, R., Wells, T., \& Johnson, W. (2003). Opening the manager's door: State probation officer stress and 
perceptions of participation in workplace decision-making. Crime and Delinquency, 49, 519-541.

Slate, R. N., \& Vogel, R. E. (1997). Participative management and correctional personnel: A study of the perceived atmosphere for participation in correctional decision making and its impact on employee stress and thoughts about quitting. Journal of Criminal Justice, 25, 397-408.

Slate, R. N., Vogel, R. E., \& Johnson, W. (2001). To quit or not to quit: Perceptions of participation in correctional decision making and the impact of organizational stress. Corrections Management Quarterly, 5, 68-78.

Slate, R. N., Johnson, W. W., \& Wells, T. L. (2000). Up to Speed: A Review of Research for Practitioners. Federal Probation, 64, 56-59.

Strelau, J., Jaworowska, A., Wrześniewski, K., \& Szczepaniak, P. (2005). Kwestionariusz Radzenia Sobie w Sytuacjach Stresowych CISS. Podręcznik [Coping Inventory for Stressful Situations Questionnaire. Textbook]. Warszawa: Pracownia Testów Psychologicznych Polskiego Towarzystwa Psychologicznego.

Świderski, A. (2006). Źródta stresu zawodowego, jego objawy i skutki ekonomiczne dla przedsiębiorstwa [Sources of job stress, its symptoms and economic impact for businesses]. Łódź: Okręgowy Inspektor Pracy w Łodzi. Retrieved from: http://www.lodz. oip.pl/pdf/referaty/01\%20Zrodla\%20stresu $\% 20$ i\%20koszty.pdf.

Tecław, S., \& Nowosielski, W. (2010). Kultura organizacyjna grup dyspozycyjnych. Komunikat z badań [Organizational culture of Uninformed Public Services. Research statement]. In: J. Maciejewski, M. Bodziany, \& K. Dojwa (eds.), Grupy dyspozycyjne w obliczu Wielkiej Zmiany. Kulturowe i spoteczne aspekty funkcjonowania w świetle procesów integracyjnych [Uninformed Public Services in the face of a great change. Cultural and social aspects of functioning in the light of integration processes]. Wrocław: Wyd. Uniwersytet Wrocławski.

Terelak, J. F. (2008). Człowiek i stres [Human and stress]. Bydgoszcz-Warszawa: Oficyna Wydawnicza Branta.

The National Council of Court probation officers (Krajowa Rada Kuratorów). (2014). Aktualna sytuacja kurateli sądowej w Polsce [The present situation of probation services in Poland]. Warszawa: Krajowa Rada Kuratorów.

Thomas, R. L. (1988). Stress perception among select federal probation and pretrial services officers and their supervisors. Federal Probation, 52, 48-58. Retrieved from: http://web.ebscohost.com.

TNS OBOP. (2008). Raport spoteczny - Polacy a czynniki ryzyka chorób układu krażenia - obejmujacy najnowsze dane dotyczące świadomości Polaków na temat czynników ryzyka chorób układu krążenia
[Social report - the Poles and risk factors for cardiovascular diseases - covering the most up-todate data concerning Polish people's awareness of the risk factors of cardiovascular diseases]. Warszawa: TNS OBOP.

Ustawa o kuratorach sadowych z dnia 27 lipca 2001 (Dz. U. z dnia 12 września 2001) [Court Probation and Supervision Officers Act of 27 July 2001].

Widerszal-Bazyl, M. Stres psychospoteczny w pracy. Pojęcie, źródta, konsekwencje [Psychosocial stress at work. Concept, sources, consequences]. Retrieved from: http://nop.ciop.pl/m5-3/m5-3_3.htm. Widerszal-Bazyl, M. (2008). Stres wśród pracowników starszych. Bezpieczeństwo pracy [Stress among older employers. Work safety]. Nauka i Praktyka, 6, 6-8.

Wirkus, Ł. (2015). Stres w pracy kuratora sadowego. Studium teoretyczno-empiryczne [Probation Officers Stress at Work. A Theoretical and Empirical Study]. Kraków: Oficyna Wydawnicza „Impuls”.

Wójcik, D. (2010). Kuratela sądowa. Sukcesy i porażki [Probation. Successes and failures]. Warszawa: Wydawnictwo Naukowe Scholar.

Zalewska, A. (2003). Dwa światy: emocjonalne i poznawcze oceny jakości życia i ich uwarunkowania u osób o wysokiej i niskiej reaktywności [Two worlds: emotional and cognitive evaluation of the quality of life and their determinants in people with high and low reactivity]. Warszawa: Wydawnictwo SWPS. 